\title{
Comparative review of Francisella tularensis and Francisella novicida
}

\section{Luke C. Kingry and Jeannine M. Petersen*}

Division of Vector-Borne Diseases, Bacterial Diseases Branch, Centers for Disease Control and Prevention, Fort Collins, CO, USA

\section{Edited by:}

Max Maurin, Université

Aix-Marseille II, France

Reviewed by:

Andrey P. Anisimov, State Research

Center for Applied Microbiology and

Biotechnology, Russia

Max Maurin, Université

Aix-Marseille II, France

*Correspondence:

Jeannine M. Petersen, Division of Vector-Borne Disease, Bacterial

Diseases Branch, Centers for

Disease Control and Prevention,

3150 Rampart Road, Fort Collins,

CO 80523, USA

e-mail:nzp0@cdc.gov
Francisella tularensis is the causative agent of the acute disease tularemia. Due to its extreme infectivity and ability to cause disease upon inhalation, $F$. tularensis has been classified as a biothreat agent. Two subspecies of $F$. tularensis, tularensis and holarctica, are responsible for tularemia in humans. In comparison, the closely related species F. novicida very rarely causes human illness and cases that do occur are associated with patients who are immune compromised or have other underlying health problems. Virulence between F. tularensis and F. novicida also differs in laboratory animals. Despite this varying capacity to cause disease, the two species share $\sim 97 \%$ nucleotide identity, with $F$. novicida commonly used as a laboratory surrogate for $F$. tularensis. As the F. novicida U112 strain is exempt from U.S. select agent regulations, research studies can be carried out in non-registered laboratories lacking specialized containment facilities required for work with virulent $F$. tularensis strains. This review is designed to highlight phenotypic (clinical, ecological, virulence, and pathogenic) and genomic differences between $F$. tularensis and F. novicida that warrant maintaining F. novicida and $F$. tularensis as separate species. Standardized nomenclature for $F$. novicida is critical for accurate interpretation of experimental results, limiting clinical confusion between $F$. novicida and $F$. tularensis and ensuring treatment efficacy studies utilize virulent $F$. tularensis strains.

\section{INTRODUCTION AND OVERVIEW}

F. tularensis was first isolated in 1912 as the causative agent of a plague-like disease affecting squirrels in Tulare county, California (McCoy and Chapin, 1912). Subsequently, Edward Francis, for whom the genus is named, established that several clinical syndromes in humans were caused by F. tularensis and proposed the name "tularemia" to describe the illness (Francis, 1925). In 1950 researchers isolated a bacterium from salt water collected from Ogden Bay, Great Salt Lake, Utah (Larson et al., 1955). Initial experiments revealed the bacterium resembled F. tularensis morphologically, but fermented sucrose, was of lesser virulence than $F$. tularensis and did not cross-react with serum from rabbits inoculated with heat, ether, formalin, or phenol killed F. tularensis (Larson et al., 1955). Based on these phenotypic differences, the isolate was given the unique species name F. novicida (Larson et al., 1955). The classification of $F$. novicida as a distinct species was further substantiated in 1964 as a result of its less fastidious growth requirements as compared to $F$. tularensis and the lack of heterologous vaccine protection in mice immunized with killed $F$. novicida and challenged with several $F$. tularensis strains (Owen et al., 1964). Additionally, guinea pigs injected subcutaneously with rabbit immune serum against either $F$. tularensis or F. novicida followed by challenge with antigen preparations from both $F$. tularensis and $F$. novicida showed antibody adsorption to homologous but not heterologous antigen at the sight of serum injections (i.e., passive cutaneous anaphylaxis assay) (Owen et al., 1964).
DNA-DNA hybridization experiments performed with F. tularensis and F. novicida in the 1980s indicated a high degree of genetic relatedness between the two $\left(\geq 92 \%\right.$ at $50^{\circ} \mathrm{C} ; \geq 86 \%$ at $65^{\circ} \mathrm{C}$ ) (Hollis et al., 1989). On this basis, it was proposed, though not validly published that $F$. novicida be reassigned as a subspecies of F. tularensis (F. tularensis subsp. novicida) (Hollis et al., 1989; Lapage, 1992; Tindall et al., 2006). To meet Bacteriological Code requirements, a proposal to transfer $F$. novicida to the subspecies rank of F. tularensis (i.e., F. tularensis subsp. novicida) was validly published in 2010 in the International Journal of Systematic and Evolutionary Microbiology (IJSEM) (Tindall et al., 2006; Huber et al., 2010). This proposal was met with formal objection in IJSEM, as it was based solely on genetic relatedness and did not take into consideration the documented phenotypic and genomic differences between F. tularensis and F. novicida (Johansson et al., 2010). Indeed, in the 2010 publication proposing reclassification of $F$. novicida, 11 metabolic traits unique to $F$. novicida as compared to $F$. tularensis were identified but not considered with respect to its suggested reassignment as $F$. tularensis subsp. novicida (Huber et al., 2010).

In recent decades, an explosion in the amount of basic research focused on understanding and treating tularemia has occurred due to concern about the intentional misuse of F. tularensis as a bioweapon (Dennis et al., 2001; Cowley and Elkins, 2011). Research studies using virulent $F$. tularensis strains can be particularly challenging, as they can only be handled under BSL-3 conditions and, in the U.S., within laboratories that are Tier 1 select agent approved (Federal 
Register, 2012). In contrast, the F. novicida type strain U112 is exempt from select agent regulations in the U.S. and can be handled under standard BSL-2 laboratory conditions (Federal Register, 2012). Information about select agent exemptions for $F$. tularensis can be found at the following website www.selectagents.gov/Select $\% 20$ Agents $\% 20$ and $\% 20$ Toxins $\% 20$ Exclusions.html\#francisella. The less stringent containment requirement for $F$. novicida $\mathrm{U} 112$, its high genetic identity to F. tularensis, its ability to infect macrophages in vitro, to cause illness in laboratory mice, and ease of genetic manipulation as compared to F. tularensis have all contributed to widespread use of F. novicida U112 as a surrogate for F. tularensis (Anthony et al., 1991; Mdluli et al., 1994; Schmerk et al., 2009; Cowley and Elkins, 2011).

To date, the appropriate nomenclature for F. novicida remains controversial and non-standardized. While F. novicida is recognized on the Approved List of Bacterial Names (Skerman et al., 1980), F. tularensis subsp. novicida is validly published (Huber et al., 2010), resulting in two different names and no clear decision on the correct nomenclature. As a result, a variety of names including, but not limited to, F. tularensis, F. tularensis subsp. novicida, Ft novicida, Ftn, Ftt, Fn, and F. novicida, have all been used in the published literature. This lack of standardized terminology is further complicated by non-enforcement of consistent nomenclature by journals and editors. It is particularly problematic when trying to interpret published experimental results obtained using $F$. novicida U112, but described only as F. tularensis with no strain information included. Another negative outcome of the proposed classification of $F$. novicida as a subspecies of F. tularensis is that other F. novicida strains, excluding the exempt U112 strain, are considered select agents in the US, despite the fact they do not cause tularemia. In order to support maintaining separate species designations for F. novicida and F. tularensis, genomic as well as clinical, virulence, ecologic and pathogenic differences between the two organisms are reviewed here (Table 1). We also discuss the utility of F. novicida as a laboratory surrogate for $F$. tularensis with respect to treatment of tularemia.

\section{HUMAN DISEASE AND TRANSMISSION}

F. tularensis is one of the most infectious bacterial pathogens known. Studies in human volunteers in the 1960s demonstrated that infection was established with as few as 25 organisms when aerogenically exposed to F. tularensis subsp. tularensis, with clinically overt disease occurring 3-5 days post exposure (McCrumb, 1961). Two subspecies of F. tularensis, tularensis (also called type A) and holarctica (also called type B), cause human tularemia (Petersen and Molins, 2010). Between these two subspecies, disease outcome and geographic distribution differs (Olsufiev et al., 1959). F. tularensis subsp. tularensis causes disease only in North America and is associated with higher mortality in humans as compared to F. tularensis subsp. holarctica, which causes less severe illness throughout the Northern Hemisphere (Olsufiev et al., 1959). Human infection due to a third subspecies, F. tularensis subsp. mediasiatica, has never been documented in the published literature.
Within both F. tularensis subsp. tularensis and subsp. holarctica, distinct subpopulations have been delineated by a number of different genotyping methods (Petersen and Molins, 2010). In the case of F. tularensis subsp. tularensis, pulsed field gel electrophoresis defined three subpopulations, A1a, A1b, and A2, which differ with respect to clinical outcome (Kugeler et al., 2009). Among patients infected with A1b strains, significantly higher fatality rates were observed as compared to those patients infected with A1a or A2 strains (Kugeler et al., 2009). The higher mortality rate for infection with an Alb strain was not associated with host factors (age, sex, underlying illness), indicating an intrinsic characteristic of Alb strains (i.e., virulence) is responsible for the observed difference (Kugeler et al., 2009).

F. tularensis causes the zoonotic, vector-borne disease tularemia. Clinical expression of tularemia in humans depends primarily on the route of transmission (Tärnvik and Berglund, 2003; WHO, 2007). Humans acquire infections by a variety of different mechanisms, including arthropod bites (ticks, flies, mosquitoes), direct contact with infected animals (e.g., skinning animals after hunting), ingestion of water or food contaminated by infected animals, and inhalation of infective aerosols (Dennis et al., 2001; WHO, 2007). For all forms, fever and acute symptoms are hallmarks of tularemia in healthy individuals. Arthropod transmission of $F$. tularensis causes glandular and ulceroglandular forms of tularemia, with the latter form of disease presenting as an ulcer at the site of the arthropod bite. Skinning infected animals also leads to ulceroglandular tularemia. Other forms of tularemia include oculoglandular tularemia, acquired via direct inoculation of the eye; oropharyngeal tularemia, acquired through ingestion of water or food contaminated by infected animals; and pneumonic (respiratory) tularemia, acquired through inhalation of infective aerosols during landscaping, farming, or laboratory activities. It is the pneumonic form of tularemia that is the most severe and of highest concern with respect to an intentional aerosol event (Dennis et al., 2001).

In comparison to F. tularensis, F. novicida infection is not associated with healthy individuals. F. novicida infection in humans is exceedingly rare and therefore often difficult to diagnose accurately (Brett et al., 2012; Birdsell et al., 2009). Only 12 cases have been documented (Hollis et al., 1989; Clarridge et al., 1996; Leelaporn et al., 2008; Birdsell et al., 2009; Brett et al., 2012; Respicio-Kingry et al., 2012; Sjödin et al., 2012; Whitehouse et al., 2012). An F. novicida-like infection was reported in an Australian patient, however, genome comparisons indicate the strain is more similar to F. hispanensis (Whipp et al., 2003; Sjödin et al., 2012). Illness caused by F. novicida does not resemble tularemia. Clinical information available for 11 reported cases indicate that 9 of the F. novicida cases occurred in patients who were immunocompromised or had underlying health problems (Hollis et al., 1989; Clarridge et al., 1996; Leelaporn et al., 2008; Birdsell et al., 2009; Brett et al., 2012; Respicio-Kingry et al., 2012; Whitehouse et al., 2012). Fever and acute disease, hallmarks of tularemia in healthy individuals, were only observed for F. novicida infections in compromised patients (Hollis et al., 1989; Clarridge et al., 1996; Leelaporn et al., 2008; Brett et al., 2012; Respicio-Kingry et al., 2012; Whitehouse et al., 2012). In the two healthy individuals with $F$. novicida infection, regional lymphadenopathy, 
Table 1 | Genetic and phenotypic differences between $F$ tularensis and $F$ novicida.

\begin{tabular}{|c|c|c|c|c|}
\hline & & F tularensis ${ }^{a}$ & F novicidab & References \\
\hline \multirow[t]{9}{*}{ Genome } & Size & $1,892,819$ bp & $1,910,031 \mathrm{bp}$ & Larsson et al., 2005; Rohmer et al., 2007 \\
\hline & Protein coding genes & 1445 & 1731 & Larsson et al., 2005; Rohmer et al., 2007 \\
\hline & Pseudogenes & 254 & 14 & Rohmer et al., 2007 \\
\hline & $\mathrm{FPI}$ & 2 copies & 1 copy & Nano et al., 2004; Larsson et al., 2005 \\
\hline & $\begin{array}{l}\text { Restriction modification } \\
\text { systems }\end{array}$ & 1 gene & $\begin{array}{l}4 \text { functional } \\
\text { systems/6 genes }\end{array}$ & Gallagher et al., 2008 \\
\hline & CRISPR/Cas & No & Yes & Sampson et al., 2013; Schunder et al., 2013 \\
\hline & O-antigen & 15 genes & $\begin{array}{l}12 \text { genes; aa identity } \\
\text { to Ft } 98 \% \text { to } 20 \%\end{array}$ & Thomas et al., 2007; Sjödin et al., 2012 \\
\hline & Recombination & No & Yes & Larsson et al., 2009 \\
\hline & IS element proliferation & Yes & No & Larsson et al., 2009 \\
\hline \multirow[t]{2}{*}{ Clinical } & Tularemia & Yes & No & Francis, 1925 \\
\hline & Transmission & $\begin{array}{l}\text { Vector-borne, animal } \\
\text { contact, inhalation of } \\
\text { aerosols }\end{array}$ & $\begin{array}{l}\text { Salt water; brackish } \\
\text { water }\end{array}$ & $\begin{array}{l}\text { Larson et al., 1955; Dennis et al., 2001; Brett } \\
\text { et al., 2012; Whitehouse et al., } 2012\end{array}$ \\
\hline \multirow[t]{2}{*}{ Ecology } & Animal hosts & $\begin{array}{l}\text { Zoonotic: small } \\
\text { mammals, } \\
\text { lagomorphs }\end{array}$ & No & Hopla, 1974; Jellison, 1974 \\
\hline & Arthropod hosts & $\begin{array}{l}\text { Ticks, flies, } \\
\text { mosquitoes }\end{array}$ & No & Jellison, 1974; Petersen et al., 2009b \\
\hline \multirow{3}{*}{$\begin{array}{l}\text { Virulence } \\
\text { (LD } 50 \text { by } \\
\text { subcutaneous or } \\
\text { intradermal } \\
\text { route of } \\
\text { infection) }\end{array}$} & Mice & $1 \mathrm{CFU}$ & $\begin{array}{l}\text { Range from } 10 \text { to } \\
>10^{7} \mathrm{CFU}\end{array}$ & $\begin{array}{l}\text { Bell et al., 1955; Larson et al., 1955; Olsufiev } \\
\text { et al., 1959; Owen et al., 1964; } \\
\text { Meshcheriakova et al., 1995; Kieffer et al., } \\
2003\end{array}$ \\
\hline & Guinea pig & $1 \mathrm{CFU}$ & $\begin{array}{l}\text { Range from } 10 \text { to } \\
>10^{5} \mathrm{CFU}\end{array}$ & $\begin{array}{l}\text { Bell et al., 1955; Olsufiev et al., 1959; } \\
\text { Meshcheriakova et al., } 1995\end{array}$ \\
\hline & Rabbit & $1 \mathrm{CFU}$ & $>10^{8} \mathrm{CFU}$ & $\begin{array}{l}\text { Olsufiev et al., 1959; Meshcheriakova et al., } \\
1995\end{array}$ \\
\hline \multirow{2}{*}{$\begin{array}{l}\text { (LD } 50 \text { by } \\
\text { intranasal or } \\
\text { intratracheal } \\
\text { route of } \\
\text { infection) }\end{array}$} & Mice & $<10 \mathrm{CFU}$ & $\begin{array}{l}\text { Approximate LD50 of } \\
10 \mathrm{CFU}\end{array}$ & Lauriano et al., 2004; Pechous et al., 2008 \\
\hline & Fischer 344 rats & $5 \times 10^{2} \mathrm{CFU}$ & $\begin{array}{l}\text { Approximate } L_{50} \text { of } \\
5 \times 10^{6} \mathrm{CFU}\end{array}$ & Ray et al., 2010 \\
\hline \multirow[t]{7}{*}{$\begin{array}{l}\text { Mechanisms of } \\
\text { pathogenicity }\end{array}$} & $\begin{array}{l}\text { Cytokine induction upon } \\
\text { cellular uptake }\end{array}$ & No & Yes & Butchar et al., 2008; Dai et al., 2013 \\
\hline & Inflammasome activation & Delayed & Yes & $\begin{array}{l}\text { Mariathasan et al., 2006; Weiss et al., 2007b; } \\
\text { Fernandes-Alnemri et al., 2010; Dotson et al., } \\
2013\end{array}$ \\
\hline & $\begin{array}{l}\text { CRISPR/cas mediated TLR2 } \\
\text { evasion }\end{array}$ & No & Yes & Dai et al., 2013; Sampson and Weiss, 2013a,b \\
\hline & PI3K/Akt signaling & $\begin{array}{l}\text { No; miR-155 } \\
\text { suppressed }\end{array}$ & $\begin{array}{l}\text { Yes; miR-155 } \\
\text { induced }\end{array}$ & Cremer et al., 2009 \\
\hline & Pulmonary cell association & $\begin{array}{l}\text { Alveolar } \\
\text { МФ/dendritic cells }\end{array}$ & $\begin{array}{l}\text { Alveolar } \\
\text { MФ/neutrophils }\end{array}$ & Hall et al., 2008 \\
\hline & O-antigen role & $\begin{array}{l}\text { Intracellular } \\
\text { replication }\end{array}$ & $\begin{array}{l}\text { Complement } \\
\text { resistance }\end{array}$ & Thomas et al., 2007; Case et al., 2014 \\
\hline & $\begin{array}{l}\text { Knockout of iclR or galE } \\
\text { genes attenuates virulence in } \\
\text { mice }\end{array}$ & No & Yes & Mortensen et al., 2010; Thomas et al., 2011 \\
\hline
\end{tabular}

a Specific numbers given are in reference to F. tularensis subsp. tularensis Schu S4, except for virulence which is from (Olsufiev et al., 1959) strain Schu.

${ }^{b}$ Specific numbers given are in reference to F. novicida U112. 
lacking fever or other symptoms, was reported (Hollis et al., 1989; Birdsell et al., 2009). Classic forms of tularemia, including ulceroglandular, pneumonic, oropharyngeal, and oculoglandular, have not been observed for F. novicida infection in healthy individuals.

Given the rarity of $F$. novicida infection in humans, little is known with regards to how the organism is transmitted. Reported human infections are associated with uncertain routes of exposure. For those cases where the mode of infection was ascertained, two cases were due to near-drowning events in salt water and three cases were associated with environmental contamination of outdoor ice machines (Brett et al., 2012; Respicio-Kingry et al., 2012; Whitehouse et al., 2012). No evidence exists to suggest that F. novicida is transmitted by animals or arthropod vectors (see Ecology section).

\section{ECOLOGY}

In nature, F. tularensis and F. novicida occupy distinct ecological niches; $F$. tularensis is a classic vector-borne zoonotic pathogen, whereas F. novicida is not. As an intracellular pathogen, F. tularensis (both subsp. tularensis and subsp. holarctica) infects and causes disease and mortality in a large number of animal hosts (Hopla, 1974; Jellison, 1974). The bacterium is most often associated with lagomorphs and rodents, including voles, squirrels, and beavers. F. tularensis is also found in nature in a number of arthropod vectors, including ticks, flies, and mosquitoes, which bite both animal and human hosts and thereby transmit the organism (Petersen et al., 2009b). Maintenance of F. tularensis in nature involves a cycle in which mammals serve as the amplifying hosts and arthropod vectors feed on these bacteremic hosts to disseminate the bacterium to other animals (Petersen et al., 2009b).

In contrast to F. tularensis, the identification of F. novicida has never been reported in wild animals (healthy or moribund), indicating that in nature $F$. novicida is not a zoonotic bacterium. F. novicida has also never been identified in arthropod vectors in nature. Moreover, in the case of arthropods, the lack of identification of F. novicida does not appear to be due to inadequate testing methods as numerous Francisellalike endosymbionts have been identified in ticks via PCR and sequencing (Scoles, 2004; Goethert and Telford, 2005; Kugeler et al., 2005; Machado-Ferreira et al., 2009; De Carvalho et al., 2011; Ivanov et al., 2011; Kreizinger et al., 2013). As arthropod vectors characteristically acquire infection from bacteremic animal hosts, the lack of identification of F. novicida in arthropods is consistent with the presumed inability $F$. novicida to cause bacteremia in wild animals. It is likely that $F$. novicida resides in an environmental niche and is propagated in nature via a mechanism that does not involve mammalian or arthropod hosts. Indeed, the sole source of F. novicida isolates to date has been salt water. This includes the F. novicida U112 type strain as well as 9 other F. novicida isolates (Larson et al., 1955; Petersen et al., 2009a; Whitehouse et al., 2012). Additional environmental sources of $F$. novicida, including brackish water and soil, have been implicated based on PCR detection and sequencing analysis (Barns et al., 2005; Kuske et al., 2006; Berrada and Telford, 2010).

\section{GENOMICS}

Genome sequencing has been performed on several F. tularensis and F. novicida strains, with a limited number of genomes fully assembled and annotated (Larsson et al., 2005; BeckstromSternberg et al., 2007; Chaudhuri et al., 2007; Rohmer et al., 2007; Barabote et al., 2009; Champion et al., 2009; Larsson et al., 2009; Modise et al., 2012; Sjödin et al., 2012; Svensson et al., 2012; Antwerpen et al., 2013). Consistent with the high degree of genetic similarity previously determined via DNA-DNA reassociation (Hollis et al., 1989), the average nucleotide identity observed across $1.1 \mathrm{MB}$ of genomic sequence from $3 \mathrm{~F}$. novicida strains and 13 F. tularensis strains (8 subsp. holarctica, 1 subsp. mediasiatica, 2 subsp. tularensis A1, and 2 subsp. tularensis A2) is $\geq 97.7 \%$ (Larsson et al., 2009). Despite this high degree of nucleotide identity, differences are apparent between their respective genomes. F. novicida U112 has a larger genome of 1,910,031 bases with more protein coding genes (1731) as compared to F. tularensis. The genome size of $F$. tularensis subsp holarctica LVS and F. tularensis subsp. tularensis Schu S4 is 1,895,998 and $1,892,819$ bases, with 1380 and 1145 protein coding genes, respectively (Rohmer et al., 2007; Larsson et al., 2009).

Selective genome reduction in the intracellular pathogen F. tularensis is clear; the F. tularensis subsp. tularensis Schu S4 and F. tularensis subsp. holarctica LVS genomes contain 254 and 303 pseudogenes, respectively (Rohmer et al., 2007). In contrast, only 14 pseudogenes are evident in the F. novicida U112 genome (Rohmer et al., 2007). Larsson et al. identified a total of 279 gene losses present in six F. tularensis genomes (3 subsp. holarctica, 1 subsp. mediasiatica, and 2 subsp. tularensis strains) as compared to the F. novicida U112 genome (Larsson et al., 2009). Frequently it is components of metabolic pathways that are deleted during the transition to an intracellular pathogen, as the nutrients can be acquired from the host. Indeed, metabolic differences between F. novicida and F. tularensis date back to early characterization of $F$. novicida, when it was found to be less fastidious compared to F. tularensis (Owen et al., 1964). More recently, Huber et al. identified 11 different metabolic traits present only in F. novicida as compared to F. tularensis subsp. tularensis, F. tularensis subsp. holarctica, and F. tularensis subsp. mediasiatica (Huber et al., 2010). Genomic analyses of F. novicida U112, F. tularensis subsp. tularensis Schu S4, and F. tularensis subsp. holarctica LVS indicate 41.2 percent of the genes predicted to be involved in amino acid biosynthesis in F. novicida U112 are inactivated in one or both F. tularensis strains (Rohmer et al., 2007). F. novicida U112 appears to have 3 incomplete amino acid synthesis pathways (lysine, histidine, and methionine) whereas in F. tularensis subsp. tularensis Schu S4 there are 9 incomplete pathways (arginine, histidine, lysine, tyrosine, methionine, cysteine, threonine, valine, and isoleucine) (Larsson et al., 2005; Rohmer et al., 2007; Meibom and Charbit, 2010; KEGG, 2014).

The F. novicida U112 genome encodes 84 genes (including those involved in amino acid biosynthesis) that are inactivated in both F. tularensis subsp. tularensis Schu S4 and F. tularensis subsp. holarctica LVS (Rohmer et al., 2007). The predicted function of these genes (carbohydrate metabolism, amino acid biosynthesis, metabolite transport, energy metabolism, transport, and DNA restriction/modification) is consistent with $F$. novicida 
maintaining the ability to exist in the environment, outside animal hosts. For example, F. novicida U112 encodes 4 intact restriction barrier systems in its genome that impair acquisition of foreign methylated DNA by as much as $10^{6}$ fold over native F. novicida U112 DNA, suggesting F. novicida resides in a niche where it encounters foreign DNA (Maier et al., 2004; Gallagher et al., 2008). The majority of genes encoding restriction barrier systems in F. tularensis genomes (subsp. tularensis Schu S4 and WY96-3418, subsp. holarctica LVS, FTA, and OSU18, and subsp. mediasiatica) are present in the form of pseudogenes, suggesting that with its transition to an intracellular pathogen, restriction barrier systems were no longer necessary for survival (Gallagher et al., 2008). This evolutionary phenomenon is also present in strains of increasing virulence in both Yersinia and Burkholderia (Ong et al., 2004; Kim et al., 2005; Gallagher et al., 2008). Another example of F. novicida retaining functions for environmental survival and persistence is the identification of 5 genes (FTN_0451-0456) encoded in the F. novicida U112 genome that are responsible for the synthesis and breakdown of the secondary messenger, bis- $\left(3^{\prime}-5^{\prime}\right)$ - cyclic dimeric GMP (cdGMP) (Zogaj et al., 2012). Overproduction of cdGMP in F. novicida U112 initiates biofilm formation as well as attenuates its ability replicate within mouse macrophages. The absence of these genes in F. tularensis suggests their elimination provided a selective advantage to its pathogenic intracellular life-cycle (Zogaj et al., 2012).

Gene amplification is evidenced in F. tularensis genomes as compared to F. novicida genomes. Most notably, genomic analyses of F. tularensis ( 6 subsp. tularensis, 12 subsp. holarctica, and 2 subsp. mediasiatica strains) and F. novicida ( 9 strains) indicate a duplication of the $30 \mathrm{kbp}$ Francisella Pathogenicity Island (FPI) in F. tularensis as compared to F. novicida which contains only a single copy (Nano et al., 2004; Larsson et al., 2005, 2009; Rohmer et al., 2007). The FPI consists of 16-19 genes comprising a Type VI secretion system (T6SS) (Nano et al., 2004; Nano and Schmerk, 2007; De Bruin et al., 2011). Deletion of most genes within the FPI of both F. tularensis and F. novicida generates mutants that are defective for intra-macrophage growth and severely attenuated for virulence in mice (Tempel et al., 2006; Maier et al., 2007; Nano and Schmerk, 2007; Bröms et al., 2010; De Bruin et al., 2011; Chou et al., 2013). Given the importance of the FPI for intracellular replication and virulence, it seems likely duplication in F. tularensis represents a unique adaptation to its intracellular niche.

Only 7 genes unique to $F$. tularensis were identified via comparative genomic analysis of $20 \mathrm{~F}$. tularensis strains (6 subsp. tularensis, 12 subsp. holarctica, and 2 subsp. mediasiatica); counterparts to these genes are absent in $9 \mathrm{~F}$. novicida strains (Sjödin et al., 2012). All 7 genes are predicted to encode components necessary for the outer surface of $F$. tularensis cells (Sjödin et al., 2012). FTT0794, FTT0795, and FTT0796 are part of $12.5 \mathrm{~kb}$ locus important for formation of a capsule-like complex on the surface of F. tularensis (Bandara et al., 2011; Zarrella et al., 2011). The proteins encoded by these genes contain conserved domains for methyltransferase (FTT0795) and phosphocholine metabolism (FTT0794 and FTT0796) (Thomas et al., 2011). FTT1453c (wzx), FTT1454c (wbtJ), and FTT1458 (wzy) encode proteins involved in lipopolysaccharide O-antigen synthesis (Sjödin et al., 2012). The wbtJ gene of F. tularensis encodes an $\mathrm{N}$-formyltransferase which converts the $\mathrm{O}$-antigen sugar, dTDP-4,6-dideoxy-4-amino-D-glucose to dTDP-4,6-dideoxy-4formamido-D-glucose, while the wzy gene product is an $\mathrm{O}$ antigen polymerase whose function is to catalyze addition of newly synthesized O-antigen repeat units (Kim et al., 2010; Zimmer et al., 2013). FTT1188 encodes a hypothetical membrane protein lacking significant homology to known proteins (Sjödin et al., 2012).

Genomic analyses indicate that $F$. tularensis and $F$. novicida evolved as two distinct populations (Larsson et al., 2009). F. tularensis strains are highly clonal, differentiating them from F. novicida strains, which are characterized by a propensity for recombination. Recombination was noted in $10 \%$ of the 742 Francisella core genes tested in seven F. novicida genomes, whereas there was no evidence of recombination in these same genes when 20 F. tularensis genomes were examined (Larsson et al., 2009; Sjödin et al., 2012). Additionally, the F. tularensis Schu S4 genome shows evidence of 79 IS element insertions compared to only 26 IS element insertions in the F. novicida U112 genome (Rohmer et al., 2007). Genome decay due to IS element proliferation is clear in F. tularensis; IS elements in F. tularensis are responsible for at least 22 percent of inactivated genes (Larsson et al., 2009). IS element proliferation in F. tularensis is also proposed to be responsible for duplication of the FPI in F. tularensis (Rohmer et al., 2007; Larsson et al., 2009). Between F. novicida and F. tularensis, substantial differences are also observed in the ratio of substitution rates at non-synonymous and synonymous sites $(\mathrm{dN} / \mathrm{dS})$, with high $\mathrm{dN} / \mathrm{dS}$ ratios for all $F$. tularensis branches, and considerably lower ratios for F. novicida (Larsson et al., 2009). Overall, these findings are consistent with the idea that niche restricted bacteria, such as intracellular pathogens, tend to have monomorphic genomes, whereas environmental bacteria are under weaker purifying selection and therefore retain the capacity to adapt to differing conditions by undergoing genomic changes (Moran, 2002; Achtman, 2008; Larsson et al., 2009).

\section{VIRULENCE}

The differing virulence between F. tularensis subspecies was classically determined by measuring the number of organisms required to kill $50-100 \%$ of infected mice, guinea pigs, and rabbits (Francis and Felton, 1953; Bell et al., 1955; Olsufiev et al., 1959). Variation in the time-to-death of $F$. tularensis-infected animals was also linked to virulence differences between $F$. tularensis subspecies (Olsufiev et al., 1959). Summarized in this section are results of virulence testing for $F$. novicida and $F$. tularensis by two routes of infection (subcutaneous and pulmonary) in mice, guinea pigs, rabbits, and rats. We note that the intent of this section is not to discuss the merits of using one animal model over another for tularemia research.

Both mice and guinea pigs are highly susceptible to F. tularensis (both subsp. tularensis and subsp. holarctica) when introduced via routes that mimic infection due to arthropod bite, with an observed $\mathrm{LD}_{100}$ of only 1 organism for subcutaneous inoculation (Bell et al., 1955; Olsufiev et al., 1959). The differing virulence 
between F. tularensis subsp. tularensis and F. tularensis subsp. holarctica in guinea pigs and mice manifests as a shortened time to death; F. tularensis subsp. tularensis infected mice and guinea pigs ( $<1000$ organisms) die markedly earlier as compared to those infected with F. tularensis subsp. holarctica (Bell et al., 1955; Olsufiev et al., 1959). Differences in time to death of infected mice are also detected between subpopulations of $F$. tularensis subsp. tularensis. Intradermal infection of C57BL/6 mice with 1020 CFUs results in significantly shortened survival times for those mice infected with A1b strains as compared to those infected with either A1a or A2 strains (Molins et al., 2010), consistent with human epidemiologic data indicating A1b strains have higher virulence than other F. tularensis subsp. tularensis strains (Kugeler et al., 2009).

In contrast to mice and guinea pigs, virulence is markedly different in rabbits between F. tularensis subsp. tularensis and F. tularensis subsp. holarctica. When introduced subcutaneously, an $\mathrm{LD}_{100}$ of 1 organism is observed for F. tularensis subsp. tularensis opposed to $10^{9}$ organisms for F. tularensis subsp. holarctica (Bell et al., 1955; Olsufiev et al., 1959). White rats are less susceptible to F. tularensis subsp. tularensis infection as compared to rabbits; an $\mathrm{LD}_{100}$ of $10^{8}-10^{9}$ was reported for subcutaneous infection by either F. tularensis subsp. tularensis or F. tularensis subsp. holarctica (Olsufiev et al., 1959).

The virulence of $F$. novicida upon subcutaneous introduction appears to be less than F. tularensis in mice, guinea pigs and rabbits, although the exact extent of the difference is difficult to quantify. There is limited data in the literature with respect to the number of $F$. novicida organisms required to kill animals as determined by $\mathrm{LD}_{50}$ or $\mathrm{LD}_{100}$ studies. Similarly, there is a lack of published data comparing time to death of animals infected with F. tularensis vs. F. novicida. Initial experiments performed with $F$. novicida U112 indicated 50 organisms introduced subcutaneously was sufficient to kill $100 \%$ (4 of 4) of infected mice and guinea pigs (Larson et al., 1955). Owen et al. subsequently reported that 10-100 cells of F. novicida U112 were required to kill a mouse and 10-1000 cells required to kill a guinea pig, although no primary data or route of infection was provided (Owen et al., 1964). Experiments using BALB/cByJ mice infected intradermally with $F$. novicida $\mathrm{U} 112$ determined an $\mathrm{LD}_{50}$ of 2400 CFU (Kieffer et al., 2003). Much higher lethal doses for F. novicida introduced subcutaneously were reported in a study published in the Russian literature (Meshcheriakova et al., 1995). An $\mathrm{LD}_{50}$ of $1.3 \times 10^{4}$ organisms and $\mathrm{LD}_{100}$ of $\sim 10^{7},>10^{8},>10^{8}$ organisms was determined upon subcutaneous infection of outbred mice with F. novicida U112, F. novicida F6168, and F. novicida D9876, respectively (Meshcheriakova et al., 1995). In the same study, an $\mathrm{LD}_{100}>10^{5}$ organisms was identified for all three $F$. novicida strains (U112, F6168, D9876) via subcutaneous infection of guinea pigs, and in rabbits no mortality was observed with $10^{8}$ organisms of each strain (Meshcheriakova et al., 1995).

In recent years, the intranasal route of infection has been used to induce respiratory illness in mice, given the severity of pneumonic tularemia and the potential impact of an intentional aerosol release of $F$. tularensis. Published studies are consistent with a difference in virulence between $F$. tularensis subsp. tularensis Schu S4 and F. novicida U112 via this route of infection.
An $\mathrm{LD}_{50}$ of $<10$ CFUs was determined for F. tularensis subsp. tularensis Schu S4 in BALB/c mice (Pechous et al., 2008) and $100 \%$ mortality is reported for infection of $\mathrm{C} 57 \mathrm{BL} / 6, \mathrm{BALB} / \mathrm{c}$, and BALB/cByJ with 13-25 CFU (Qin et al., 2008; Cong et al., 2009; Child et al., 2010; Okan et al., 2013; Richard et al., 2014). For F. novicida U112, an approximate $\mathrm{LD}_{50}$ of $10 \mathrm{CFU}$ was determined in inbred mice by intranasal inoculation, with two of five $\mathrm{BALB} / \mathrm{c}$ mice surviving an inoculum of $30 \mathrm{CFU}$, and one of five surviving an inoculum of $300 \mathrm{CFU}$ (Lauriano et al., 2004). In $\mathrm{C} 57 \mathrm{BL} / 6$ and $\mathrm{BALB} / \mathrm{c}$ mice, $100 \%$ mortality is reported using doses ranging from 100 to 445 CFU of F. novicida U112 (Pammit et al., 2004; Mares et al., 2008; Sharma et al., 2009).

Significant virulence differences between $F$. tularensis and F. novicida are evident upon pulmonary infection of Fischer 344 rats via intratracheal instillation (Ray et al., 2010). Fischer 344 rats show the highest sensitivity to F. tularensis subsp. tularensis Schu $\mathrm{S} 4$ (approximate $\mathrm{LD}_{50}$ of $5 \times 10^{2} \mathrm{CFU}$ ) as compared to F. tularensis subsp. holarctica OR96-0246 (approximate $\mathrm{LD}_{50}$ of $1 \times 10^{5}$ CFU) (Ray et al., 2010). In contrast, Fischer 344 rats are highly resistant to $F$. novicida $\mathrm{U} 112$ infection, with an approximate $\mathrm{LD}_{50}$ of $5 \times 10^{6} \mathrm{CFU}$ (Ray et al., 2010). Of note, a rapid time to death $(\mathrm{MTD}=3$ days) was observed in the rats which succumbed to infection with $F$. novicida, as compared to rats which died due to infection with $F$. tularensis (MTD $=10$ days), suggesting death due to $F$. novicida was likely a toxic effect from the large number of organisms rather than from a productive infection (Ray et al., 2010).

\section{MECHANISMS OF PATHOGENESIS}

As described in this review, the genomes of $F$. novicida and F. tularensis are highly similar, with the vast majority of genes in F. tularensis also found in F. novicida. Despite this overall genetic similarity, evidence indicates differential regulation of and distinct roles for homologous genes in F. tularensis and F. novicida as pertains to pathogenesis. Moreover, F. tularensis has developed strategies distinct from F. novicida to evade host immune responses. This section will focus on some of the differences that have been described to date.

Evidence that the same genes in F. novicida and F. tularensis play distinct roles in pathogenesis comes from knockout studies of homologous genes. For example, inactivation of the genes encoding the transcriptional regulator IclR or the UDP-glucose4-epimerase GalE resulted in attenuation of F. novicida U112, but not F. tularensis subsp. tularensis Schu S4 in a mouse model of infection (Weiss et al., 2007a; Mortensen et al., 2010; Thomas et al., 2011). In the case of the $d s b B$ gene, which encodes disulfide bond formation B protein, deletion mutants were attenuated in both F. tularensis subsp. tularensis Schu S4 and F. novicida U112. However, F. novicida U112 knockouts provided protection from challenge with F. novicida U112, while F. tularensis subsp. tularensis Schu S4 mutants provided no homologous protection (Tempel et al., 2006; Qin et al., 2008). Intramacrophage secretion of FPI proteins also differs between $F$. tularensis and $F$. novicida. Upon infection of macrophages, 8 FPI proteins (IglE, IglC, IglI, IglJ, IglF, VgrF, PdpE, and PdpA) were secreted by F. tularensis subsp. holarctica LVS, whereas only 4 (IglE, IglC, PdpE, and PdpA) were secreted by $F$. novicida, suggesting fundamental differences may 
exist between the two species with respect to the Type VI secretion mechanism (Bröms et al., 2012).

The cell surface, a critical pathogenicity determinant, differs between $F$. tularensis and F. novicida. Early studies indicated a lack of serum cross-reactivity between $F$. tularensis and F. novicida. More recently all genes unique to $F$. tularensis as compared to F. novicida were predicted to encode outer surface components (see Genomics section) (Larson et al., 1955; Owen et al., 1964; Sjödin et al., 2012). Indeed, distinct structures for the core oligosaccharide and $\mathrm{O}$-antigen of $\mathrm{F}$. tularensis and $\mathrm{F}$. novicida LPS have been described. The core oligosaccharide of F. tularensis lacks a glucose residue attached to the $\beta$-glucose branch as compared to F. novicida (Vinogradov et al., 2002; Vinogradov and Perry, 2004; Gunn and Ernst, 2007; Okan and Kasper, 2013), while the O-antigen of F. tularensis contains two distinct sugar moieties at either end of the tetra-saccharide repeat and is present in longer oligomer chains as compared to F. novicida (Vinogradov et al., 2004; Thomas et al., 2007; Barker et al., 2014). Reflecting the observed structural variation, three of the genes in the $\mathrm{O}$-antigen encoding locus are unique to F. tularensis (see Genomics section) and among the other 12 genes, amino acid identity ranges from $98 \%$ to as low as $20 \%$ (Thomas et al., 2007; Sjödin et al., 2012). The structurally and antigentically unique $O$-antigens from $F$. tularensis and $F$. novicida appear to play different roles in the pathogenicity of each strain. In F. tularensis, the $\mathrm{O}$-antigen is critical for intracellular survival as an $\mathrm{O}$-antigen mutant (wbtDEF) (Thomas et al., 2007; Jones et al., 2012) is significantly attenuated for intracellular growth as compared to a similar wbtDEF mutant in F. novicida, which replicates normally in macrophages (Thomas et al., 2007). Recent evidence indicates that the O-antigen of F. tularensis subsp. tularensis Schu S4 protects it from autophagic detection once it reaches the cytosol (Case et al., 2014).

The cell surface of $F$. tularensis also plays an important role in cell entry and evasion of the host innate immune response. Within host serum, the function of complement proteins is to recognize pathogens and protect the host by direct lysis of the pathogen or opsonization leading to phagocytosis. Both F. tularensis and F. novicida have been shown to fix human complement protein $\mathrm{C} 3$ on their surface, but are resistant to complement mediated lysis due to rapid conversion of $\mathrm{C} 3 \mathrm{~b}$ to $\mathrm{C} 3 \mathrm{bi}$ (Clay et al., 2008). This conversion of C3 leads to the interaction of C3bi with complement receptor protein C3R on host cells and cellular uptake by phagocytosis (Clemens et al., 2005; Ben Nasr and Klimpel, 2008; Clay et al., 2008; Dai et al., 2013). Deposition of C3 on F. novicida has been shown to increase both the production of reactive oxygen species (ROS) by human neutrophils and the production of TNF $\alpha$, IL- 6 , and IL- $1 \beta$ by human monocytes (Barker et al., 2009; Dai et al., 2013). In stark contrast, C3 deposition on F. tularensis subsp. holarctica LVS resulted in significantly less ROS production by human neutrophils, and C3 deposition on F. tularensis subsp. tularensis Schu S4 was directly linked to suppression of the host immune response as monitored by the decreased production of the proinflammatory cytokines, $\mathrm{TNF} \alpha$, IL-6, and IL-1 $\beta$, during uptake by human monocytes (Barker et al., 2009; Dai et al., 2013). Taken together, these results suggest different means of cellular entry for F. tularensis and
F. novicida and also differential effects on the early host immune response.

A side-by-side comparison of pulmonary infection by F. tularensis or F. novicida in C57BL/6 mice demonstrated dissimilar cell types were infected in vivo. One day post-infection, via the intranasal route, F. tularensis subsp. tularensis Schu S4, F. tularensis subsp. holarctica LVS, and F. novicida U112 were preferentially associated with alveolar macrophages, although this proportion differed at $78.9,70.3$, and $51.6 \%$, respectively (Hall et al., 2008). Strikingly, $27.3 \%$ of F. novicida infected cells on day 1 were neutrophils as compared to only 0 and $0.4 \%$ for F. tularensis subsp. tularensis Schu S4 and F. tularensis subsp. holarctica LVS, respectively (1000 fold difference in the number of neutrophils), indicating that neutrophils responded to and phagocytosed F. novicida U112 to a significantly greater extent than they did F. tularensis (Hall et al., 2008). Moreover, increasing numbers of alveolar macrophages and dendritic cells were infected from day 1 to 3 following inhalation with either F. tularensis subsp. tularensis Schu S4 or F. tularensis subsp. holarctica LVS, but not for F. novicida U112, suggesting more rapid killing of F. novicida infected cells (Hall et al., 2008).

Within host cells, F. tularensis and F. novicida display distinct abilities to evade the host immune response. The formation of the inflammasome, a multi-protein complex present in the host cell cytoplasm, is activated by microbial components to induce maturation of the inflammatory cytokines, interleukin IL-1 $\beta$ and IL-18, thereby leading to death of infected cells (Bauernfeind and Hornung, 2013). F. novicida is unable to efficiently evade this host innate immune response, and is recognized by the inflammasome upon escape from the phagosome and entry into the host cell cytoplasm (Mariathasan et al., 2006; Weiss et al., 2007b; Fernandes-Alnemri et al., 2010; Jones et al., 2012; Dotson et al., 2013). In contrast, $F$. tularensis successfully escapes inflammasome activation early in infection $(\sim 12 \mathrm{~h})$ via a mechanism involving suppression of TLR2 signaling (Dotson et al., 2013). Presumably, this early suppression of the inflammasome allows F. tularensis time to successfully replicate to high levels in the cytoplasm prior to host cell death (Dotson et al., 2013).

Toll-like receptors (TLRs) play a central role in initiating innate cellular immune responses (Lim and Staudt, 2013). Evasion of TLR2 signaling has been shown to be involved in the intracellular replication of both $F$. tularensis and $F$. novicida, although the mechanism utilized diverges between the two bacteria (Telepnev et al., 2003; Katz et al., 2006; Malik et al., 2006; Abplanalp et al., 2009; Dai et al., 2013). Within the phagosome, F. novicida down-regulates the production of an endogenous transcript (FTN_1103), encoding a TLR2 stimulating lipoprotein, in a CRISPR/Cas system dependent manner (Sampson et al., 2013; Sampson and Weiss, 2013a,b). In contrast, F. tularensis lacks both the functional CRISPR/Cas system as well as the FTN_1103 homolog; genomic analyses indicate significant disruption/degradation of these genes (Schunder et al., 2013; Sampson and Weiss, 2013b). Rather, F. tularensis appears to evade TLR2 activation via a mechanism that involves the PI3K/Akt pathway, which when activated leads to production of the pro-inflammatory cytokines IL-6, IL-8, and IL-1 $\beta$ (Butchar et al., 2008; Cremer et al., 2009, 2011; Medina et al., 2010). The 
$\mathrm{P} 13 \mathrm{~K} /$ Act pathway is subject to negative regulation by the enzyme SHIP and a cellular micro-RNA, miR-155 (Cremer et al., 2009, 2011). Induction of miR-155 down-regulates SHIP to promote activation of the P13/Act pathway and inflammatory cytokine production. F. tularensis subverts or suppresses the induction of miR-155, thereby repressing the PI3K/Akt pathway. In contrast, F. novicida strongly induces miR-155, leading to activation of the P13K/Act pathway and the production of TNF $\alpha$ and IL- 6 by human monocytes (Cremer et al., 2009, 2011).

\section{TREATMENT}

Development of novel therapeutics for the treatment of tularemia is an area of active research given concern regarding the potential misuse of F. tularensis as a bioweapon. Standard antimicrobial therapy is effective for the treatment of tularemia, with aminoglycosides, tetracyclines, and chloramphenicol approved for treatment of tularemia by the U.S. Food and Drug Administration. Although ciprofloxacin and other fluoroquinolones are not currently FDA-approved for treatment of tularemia, they show very good efficacy against $F$. tularensis in vitro, in animals, and in humans (Johansson et al., 2000, 2002; Steward et al., 2006; Klimpel et al., 2008; Meric et al., 2008; Urich and Petersen, 2008; Nelson et al., 2010; Weber et al., 2012).

Antibiotic resistance to frontline therapeutics recommended for treatment of tularemia has never been identified in naturally occurring strains of $F$. tularensis or F. novicida (Ikäheimo et al., 2000; Garcia Del Blanco et al., 2004; Tomaso et al., 2005; Urich and Petersen, 2008; Valade et al., 2008; Georgi et al., 2012). Although treatment failure has been documented for human cases of tularemia, it is not associated with spontaneous antibiotic resistance, but rather a delay in antibiotic initiation (Celebi et al., 2006; Meric et al., 2008; Kaya et al., 2011). Nonetheless, antibiotic resistance remains a concern, whether spontaneous or intentionally engineered. In vitro experiments demonstrate that both $F$. tularensis and F. novicida have the ability to rapidly acquire resistance to quinolones. Passage of either F. tularensis subsp. holarctica LVS or F. novicida U112 on increasing concentrations of ciprofloxacin resulted in resistance to homologous classes of drugs (Sutera et al., 2014). Of note, in the case of F. novicida, but not $F$. tularensis subsp. holarctica, cross-resistance to heterologous classes of antimicrobials, including doxycycline and erythromycin, was observed (Sutera et al., 2014). This suggests F. novicida U112 encodes other genes not present in F. tularensis that confer multidrug resistance and is consistent with genomic comparisons indicating more transporters are present in the genome of F. novicida U112 (Rohmer et al., 2007; Sutera et al., 2014).

New therapeutic approaches for tularemia range from targeting the organism itself to modulating the host response in order to mount a protective response. These therapeutic approaches are covered in other chapters of this series. For approval and licensure of new therapeutics for tularemia, direct evaluation of the product's efficacy in a clinical setting is needed. Because therapeutic efficacy testing is not always feasible in a clinical setting (e.g., limited numbers of cases), the U.S. Food and Drug Administration developed the "Animal Rule" (21 CFR 314.610 and 21 CFR 601.91) to allow animal efficacy data to support product licensure or approval. Of note with respect to F. tularensis and F. novicida, the "Animal Rule" states that the etiological agent used in animal studies generally should be identical to the one that causes human disease. As discussed above, F. novicida does not cause tularemia in humans and differences between $F$. novicida and F. tularensis are also apparent in animals, indicating that F. novicida should not substitute for F. tularensis in efficacy testing of therapeutics. As recent studies indicate virulence differs among F. tularensis subsp. tularensis strains in humans (Kugeler et al., 2009; Molins et al., 2010), the use of more virulent A1b strains should be considered for therapeutic efficacy testing in animals.

\section{CONCLUSIONS AND PERSPECTIVE}

Bacterial species have traditionally been defined on the basis of DNA-DNA hybridization values (Lapage, 1992; Stackebrandt et al., 2002). The importance of phenotypic differences, however, cannot be understated with respect to classification of bacterial species. In 2002, the ad-hoc committee for the re-evaluation of bacterial species definition stated: "Phenotype, including chemotaxonomic markers, will remain important diagnostic properties in a species description. The ecological role can, in certain cases, decide on the species status. For example, medical organisms with defined clinical symptoms may continue to bear names that may not necessarily agree with their genomic relatedness so as to avoid unnecessary confusion among microbiologists and nonmicrobiologists ['nomen periculosum' according to Rule 56a(5) of the International Code of Nomenclature of Bacteria (Lapage, 1992)]" (Stackebrandt et al., 2002). A classic example of the value in utilizing phenotypic data to maintain distinct species designations comes from the bacteria Yersinia pestis and Yersinia pseudotuberculosis. Although these two bacteria share $>97 \%$ nucleotide identity across $75 \%$ of their genes, they retain individual species names, due to their striking clinical and ecological differences (Chain et al., 2004; Carniel et al., 2006). Y. pestis causes the highly fatal vector-borne disease, plague, whereas Y. pseudotuberculosis is transmitted by the fecal-oral route and infection rarely leads to death.

In this review, we have highlighted clinical, ecological, genomic, virulence, and pathogenic differences between $F$. novicida and $F$. tularensis that when considered in conjunction with genetic identity clearly warrants maintaining F. novicida and F. tularensis as separate species (Table 1). F. tularensis causes the zoonotic vector-borne disease tularemia, whereas $F$. novicida does not. As determined by whole genome comparisons, F. tularensis evolved independently of F. novicida, which is consistent with its completely distinct ecological niche (F. tularensis is a zoonotic pathogen whereas $F$. novicida is not) and mechanisms of transmission (F. tularensis is transmitted by arthropod vectors whereas F. novicida is not). Moreover, as part of F. tularensis' pathogenic intracellular lifestyle, it has developed strategies distinct from F. novicida to evade host immune responses and successfully propagate in animal hosts.

F. novicida and its mutants have clearly contributed to our understanding of the biology of F. tularensis. A classic example was the discovery of the $30 \mathrm{kbp}$ FPI in F. novicida (Gray et al., 2002; Nano et al., 2004). In more recent years, side-by-side 
experiments including both F. novicida and F. tularensis have highlighted the value of direct comparison between the two as pertains to understanding the unique pathogenic mechanisms F. tularensis has evolved to elicit its extreme virulence (Vinogradov et al., 2002, 2004; Vinogradov and Perry, 2004; Thomas et al., 2007; Butchar et al., 2008; Hall et al., 2008; Cremer et al., 2009; Mortensen et al., 2010; Bröms et al., 2012; Dai et al., 2013; Dotson et al., 2013; Sutera et al., 2014). As we move forward, findings utilizing the select agent exempt $F$. novicida U112 strain will no doubt continue to provide novel insight into the closely related species, F. tularensis. It is essential, however, to keep the two species separate and utilize standardized nomenclature for F. novicida. The recognition of F. novicida as a separate species via consistent and accepted nomenclature will limit misinterpretation of experimental results as pertains to the human disease tularemia caused by $F$. tularensis, avoid confusion between $F$. tularensis and F. novicida in clinical settings and ensure F. tularensis strains are used for treatment efficacy studies.

\section{REFERENCES}

Abplanalp, A. L., Morris, I. R., Parida, B. K., Teale, J. M., and Berton, M. T. (2009). TLR-dependent control of Francisella tularensis infection and host inflammatory responses. PLoS ONE 4:e7920. doi: 10.1371/journal.pone.0007920

Achtman, M. (2008). Evolution, population structure, and phylogeography of genetically monomorphic bacterial pathogens. Annu. Rev. Microbiol. 62, 53-70. doi: 10.1146/annurev.micro.62.081307.162832

Anthony, L. S., Gu, M. Z., Cowley, S. C., Leung, W. W., and Nano, F. E. (1991). Transformation and allelic replacement in Francisella spp. J. Gen. Microbiol. 137, 2697-2703.

Antwerpen, M. H., Schacht, E., Kaysser, P., and Splettstoesser, W. D. (2013). Complete genome sequence of a Francisella tularensis subsp. holarctica strain from Germany causing lethal infection in common marmosets. Genome Announc. 1:e00135. doi: 10.1128/genomeA.00135-12

Bandara, A. B., Champion, A. E., Wang, X., Berg, G., Apicella, M. A., McLendon, M., et al. (2011). Isolation and mutagenesis of a capsule-like complex (CLC) from Francisella tularensis, and contribution of the CLC to $F$. tularensis virulence in mice.PLoS ONE 6:e19003. doi: 10.1371/journal.pone.0019003

Barabote, R. D., Xie, G., Brettin, T. S., Hinrichs, S. H., Fey, P. D., Jay, J. J., et al. (2009). Complete genome sequence of Francisella tularensis subspecies holarctica FTNF002-00. PLoS ONE 4:e7041. doi: 10.1371/journal.pone.0007041

Barker, J. H., Kaufman, J. W., Zhang, D. S., and Weiss, J. P. (2014). Metabolic labeling to characterize the overall composition of Francisella Lipid A and LPS grown in broth and in human phagocytes. Innate Immun. 20, 88-103. doi: 10.1177/ 1753425913485308

Barker, J. R., Chong, A., Wehrly, T. D., Yu, J. J., Rodriguez, S. A., Liu, J., et al. (2009). The Francisella tularensis pathogenicity island encodes a secretion system that is required for phagosome escape and virulence. Mol. Microbiol. 74, 1459-1470. doi: 10.1111/j.1365-2958.2009.06947.x

Barns, S. M., Grow, C. C., Okinaka, R. T., Keim, P., and Kuske, C. R. (2005). Detection of diverse new Francisella-like bacteria in environmental samples. Appl. Environ. Microbiol. 71, 5494-5500. doi: 10.1128/AEM.71.9.54945500.2005

Bauernfeind, F., and Hornung, V. (2013). Of inflammasomes and pathogenssensing of microbes by the inflammasome. EMBO Mol. Med. 5, 814-826. doi: 10.1002/emmm.201201771

Beckstrom-Sternberg, S. M., Auerbach, R. K., Godbole, S., Pearson, J. V., Beckstrom-Sternberg, J. S., Deng, Z., et al. (2007). Complete genomic characterization of a pathogenic A.II strain of Francisella tularensis subspecies tularensis. PLoS ONE 2:e947. doi: 10.1371/journal.pone.0000947

Bell, J. F., Owen, C. R., and Larson, C. L. (1955). Virulence of Bacterium tularense. I. A study of the virulence of Bacterium tularense in mice, guinea pigs, and rabbits. J. Infect. Dis. 97, 162-166.

Ben Nasr, A., and Klimpel, G. R. (2008). Subversion of complement activation at the bacterial surface promotes serum resistance and opsonophagocytosis of Francisella tularensis. J. Leukoc. Biol. 84, 77-85. doi: 10.1189/jlb.0807526
Berrada, Z. L., and Telford, S. R. 3rd. (2010). Diversity of Francisella species in environmental samples from Martha's Vineyard, Massachusetts. Microb. Ecol. 59, 277-283. doi: 10.1007/s00248-009-9568-y

Birdsell, D. N., Stewart, T., Vogler, A. J., Lawaczeck, E., Diggs, A., Sylvester, T. L., et al. (2009). Francisella tularensis subsp. novicida isolated from a human in Arizona. BMC Res. Notes 2:223. doi: 10.1186/1756-0500-2-223

Brett, M., Doppalapudi, A., Respicio-Kingry, L. B., Myers, D., Husband, B., Pollard, K., et al. (2012). Francisella novicida bacteremia after a near-drowning accident. J. Clin. Microbiol. 50, 2826-2829. doi: 10.1128/JCM.00995-12

Bröms, J. E., Meyer, L., Sun, K., Lavander, M., and Sjöstedt, A. (2012). Unique substrates secreted by the type VI secretion system of Francisella tularensis during intramacrophage infection. PLoS ONE 7:e50473. doi: 10.1371/journal.pone. 0050473

Bröms, J. E., Sjöstedt, A., and Lavander, M. (2010). The role of the Francisella tularensis pathogenicity island in Type VI secretion, intracellular survival, and modulation of host cell signaling. Front. Microbiol. 1:136. doi: 10.3389/fmicb.2010.00136

Butchar, J. P., Cremer, T. J., Clay, C. D., Gavrilin, M. A., Wewers, M. D., Marsh, C. B., et al. (2008). Microarray analysis of human monocytes infected with Francisella tularensis identifies new targets of host response subversion. PLoS ONE 3:e2924. doi: 10.1371/journal.pone.0002924

Carniel, E. A. I., Cornelis, G., Fukushima, H., Guinet, F., Isberg, R., Pham, J. et al. (2006). "Y. enterocolitica and Y. pseudotuberculosis," in The Prokaryotes: A Handbook on the Biology of Bacteria, 3rd Edn., eds M. Dworkin, S. Falkow, E. Rosenberg, K.-H. Schleifer, and E. Stackebrandt (New York, NY: Springer Verlag), 270-398.

Case, E. D., Chong, A., Wehrly, T. D., Hansen, B., Child, R., Hwang, S., et al. (2014). The Francisella O-antigen mediates survival in the macrophage cytosol via autophagy avoidance. Cell. Microbiol. doi: 10.1111/cmi.12246. [Epub ahead of print].

Celebi, G., Baruonu, F., Ayoglu, F., Cinar, F., Karadenizli, A., Ugur, M. B., et al. (2006). Tularemia, a reemerging disease in northwest Turkey: epidemiological investigation and evaluation of treatment responses. Jpn. J. Infect. Dis. 59, 229-234.

Chain, P. S., Carniel, E., Larimer, F. W., Lamerdin, J., Stoutland, P. O., Regala, W. M., et al. (2004). Insights into the evolution of Yersinia pestis through whole-genome comparison with Yersinia pseudotuberculosis. Proc. Natl. Acad. Sci. U.S.A. 101, 13826-13831. doi: 10.1073/pnas.0404012101

Champion, M. D., Zeng, Q., Nix, E. B., Nano, F. E., Keim, P., Kodira, C. D., et al. (2009). Comparative genomic characterization of Francisella tularensis strains belonging to low and high virulence subspecies. PLoS Pathog. 5:e1000459. doi: 10.1371/journal.ppat.1000459

Chaudhuri, R. R., Ren, C. P., Desmond, L., Vincent, G. A., Silman, N. J., Brehm, J. K., et al. (2007). Genome sequencing shows that European isolates of Francisella tularensis subspecies tularensis are almost identical to US laboratory strain Schu S4. PLoS ONE 2:e352. doi: 10.1371/journal.pone.0000352

Child, R., Wehrly, T. D., Rockx-Brouwer, D., Dorward, D. W., and Celli, J. (2010). Acid phosphatases do not contribute to the pathogenesis of type A Francisella tularensis. Infect. Immun. 78, 59-67. doi: 10.1128/IAI. 00965-09

Chou, A. Y., Kennett, N. J., Nix, E. B., Schmerk, C. L., Nano, F. E., and Elkins, K. L. (2013). Generation of protection against Francisella novicida in mice depends on the pathogenicity protein PdpA, but not PdpC or PdpD. Microbes Infect. 15, 816-827. doi: 10.1016/j.micinf.2013.07.005

Clarridge, J. E. 3rd., Raich, T. J., Sjösted, A., Sandström, G., Darouiche, R. O., Shawar, R. M., et al. (1996). Characterization of two unusual clinically significant Francisella strains. J. Clin. Microbiol. 34, 1995-2000.

Clay, C. D., Soni, S., Gunn, J. S., and Schlesinger, L. S. (2008). Evasion of complement-mediated lysis and complement C3 deposition are regulated by Francisella tularensis lipopolysaccharide O antigen. J. Immunol. 181, 5568-5578.

Clemens, D. L., Lee, B. Y., and Horwitz, M. A. (2005). Francisella tularensis enters macrophages via a novel process involving pseudopod loops. Infect. Immun. 73 , 5892-5902. doi: 10.1128/IAI.73.9.5892-5902.2005

Cong, Y., Yu, J. J., Guentzel, M. N., Berton, M. T., Seshu, J., Klose, K. E. et al. (2009). Vaccination with a defined Francisella tularensis subsp. novicida pathogenicity island mutant (DeltaiglB) induces protective immunity against homotypic and heterotypic challenge.Vaccine 27, 5554-5561. doi: 10.1016/j.vaccine.2009.07.034 
Cowley, S. C., and Elkins, K. L. (2011). Immunity to Francisella. Front. Microbiol. 2:26. doi: 10.3389/fmicb.2011.00026

Cremer, T. J., Butchar, J. P., and Tridandapani, S. (2011). Francisella subverts innate immune signaling: focus on PI3K/Akt. Front. Microbiol. 5:13. doi: 10.3389/fmicb.2011.00013

Cremer, T. J., Ravneberg, D. H., Clay, C. D., Piper-Hunter, M. G., Marsh, C. B., Elton, T. S., et al. (2009). MiR-155 induction by F. novicida but not the virulent F. tularensis results in SHIP down-regulation and enhanced pro-inflammatory cytokine response. PLoS ONE 4:e8508. doi: 10.1371/journal.pone.0008508

Dai, S., Rajaram, M. V., Curry, H. M., Leander, R., and Schlesinger, L. S. (2013). Fine tuning inflammation at the front door: macrophage complement receptor 3-mediates phagocytosis and immune suppression for Francisella tularensis. PLoS Pathog. 9:e1003114. doi: 10.1371/journal.ppat.1003114

De Bruin, O. M., Duplantis, B. N., Ludu, J. S., Hare, R. F., Nix, E. B., Schmerk, C. L., et al. (2011). The biochemical properties of the Francisella pathogenicity island (FPI)-encoded proteins IglA, IglB, IglC, PdpB and DotU suggest roles in type VI secretion. Microbiology 157, 3483-3491. doi: 10.1099/mic.0.052308-0

De Carvalho, I. L. S. N., Soares, T., Ze-Ze, L., Nuncio, M. S. (2011). Francisellalike endosymbiont in Dermacentor reticulatus collected in Portugal. Vector Borne Zoonotic Dis. 11, 185-188. doi: 10.1089/vbz.2010.0014

Dennis, D. T., Inglesby, T. V., Henderson, D. A., Bartlett, J. G., Ascher, M. S., Eitzen, E., et al. (2001). Tularemia as a biological weapon: medical and public health management. J. Am. Med. Assoc. 285, 2763-2773. doi: 10.1001/jama.285.21.2763

Dotson, R. J., Rabadi, S. M., Westcott, E. L., Bradley, S., Catlett, S. V., Banik, S., et al. (2013). Repression of inflammasome by Francisella tularensis during early stages of infection. J. Biol. Chem. 288, 23844-23857. doi: 10.1074/jbc.M113.490086

Federal Register. (2012). Possession, Use, and Transfer of Select Agents and Toxins. 61083-61115. Available online at: https://federalregister.gov/a/2012-24389

Fernandes-Alnemri, T., Yu, J. W., Juliana, C., Solorzano, L., Kang, S., Wu, J., et al. (2010). The AIM2 inflammasome is critical for innate immunity to Francisella tularensis. Nat. Immunol. 11, 385-393. doi: 10.1038/ni.1859

Francis, E. (1925). Tularemia. J. Am. Med. Assoc. 84, 1243-1250.

Francis, E., and Felton, L. (1953). The isolation from the rocky mountain wood tick (Dermacentor andersoni) of strains of Bact. tularense of low virulence for guinea pigs and domestic rabbits. Public Health Rep. 57:44.

Gallagher, L. A., McKevitt, M., Ramage, E. R., and Manoil, C. (2008). Genetic dissection of the Francisella novicida restriction barrier. J. Bacteriol. 190, 7830-7837. doi: 10.1128/JB.01188-08

Garcia Del Blanco, N., Gutierrez Martin, C. B., De La Puente Redondo, V. A., and Rodriguez Ferri, E. F. (2004). In vitro susceptibility of field isolates of Francisella tularensis subsp. holarctica recovered in Spain to several antimicrobial agents. Res. Vet. Sci. 76, 195-198. doi: 10.1016/j.rvsc.2003.12.002

Georgi, E., Schacht, E., Scholz, H. C., and Splettstoesser, W. D. (2012). Standardized broth microdilution antimicrobial susceptibility testing of Francisella tularensis subsp. holarctica strains from Europe and rare Francisella species.J. Antimicrob. Chemother. 67, 2429-2433. doi: 10.1093/jac/dks238

Goethert, H. K., and Telford, S. R. 3rd. (2005). A new Francisella (Beggiatiales: Francisellaceae) inquiline within Dermacentor variabilis say (Acari: Ixodidae). J. Med. Entomol. 42, 502-505. doi: 10.1603/0022-2585(2005)042\%5B0502:ANFBFI\%5D2.0.CO;2

Gray, C. G., Cowley, S. C., Cheung, K. K., and Nano, F. E. (2002). The identification of five genetic loci of Francisella novicida associated with intracellular growth. FEMS Microbiol. Lett. 215, 53-56. doi: 10.1016/S0378-1097(02)00911-4

Gunn, J. S., and Ernst, R. K. (2007). The structure and function of Francisella lipopolysaccharide. Ann. N.Y. Acad. Sci. 1105, 202-218. doi: 10.1196/annals.1409.006

Hall, J. D., Woolard, M. D., Gunn, B. M., Craven, R. R., Taft-Benz, S., Frelinger, J. A., et al. (2008). Infected-host-cell repertoire and cellular response in the lung following inhalation of Francisella tularensis Schu S4, LVS, or U112. Infect. Immun. 76, 5843-5852. doi: 10.1128/IAI.01176-08

Hollis, D. G., Weaver, R. E., Steigerwalt, A. G., Wenger, J. D., Moss, C. W., and Brenner, D. J. (1989). Francisella philomiragia comb. nov. (formerly Yersinia philomiragia) and Francisella tularensis biogroup novicida (formerly Francisella novicida) associated with human disease. J. Clin. Microbiol. 27, 1601-1608.

Hopla, C. E. (1974). The ecology of tularemia. Adv. Vet. Sci. Comp. Med. 18, 25-53.

Huber, B., Escudero, R., Busse, H. J., Seibold, E., Scholz, H. C., Anda, P., et al. (2010). Description of Francisella hispaniensis sp. nov., isolated from human blood, reclassification of Francisella novicida (Larson et al. 1955) Olsufiev et al.
1959 as Francisella tularensis subsp. novicida comb. nov. and emended description of the genus Francisella. Int. J. Syst. Evol. Microbiol. 60, 1887-1896. doi: 10.1099/ijs.0.015941-0

Ikäheimo, I., Syrjälä, H., Karhukorpi, J., Schildt, R., and Koskela, M. (2000). In vitro antibiotic susceptibility of Francisella tularensis isolated from humans and animals. J. Antimicrob. Chemother. 46, 287-290. doi: 10.1093/jac/46.2.287

Ivanov, I. N., Mitkova, N., Reye, A. L., Hubschen, J. M., Vatcheva-Dobrevska, R. S., Dobreva, E. G., et al. (2011). Detection of new Francisella-like tick endosymbionts in Hyalomma spp. and Rhipicephalus spp. (Acari: Ixodidae) from Bulgaria.Appl. Environ. Microbiol. 77, 5562-5565. doi: 10.1128/AEM. 02934-10

Jellison, W. (1974). Tularemia in North America. Missoula, MT: University of Montana Foundation.

Johansson, A., Berglund, L., Gothefors, L., Sjöstedt, A., and Tärnvik, A. (2000). Ciprofloxacin for treatment of tularemia in children. Pediatr. Infect. Dis. J. 19, 449-453. doi: 10.1097/00006454-200005000-00011

Johansson, A., Celli, J., Conlan, W., Elkins, K. L., Forsman, M., Keim, P. S., et al. (2010). Objections to the transfer of Francisella novicida to the subspecies rank of Francisella tularensis. Int. J. Syst. Evol. Microbiol. 60, 1717-1718; author reply 1718-1720. doi: 10.1099/ijs.0.022830-0

Johansson, A., Urich, S. K., Chu, M. C., Sjöstedt, A., and Tärnvik, A. (2002). In vitro susceptibility to quinolones of Francisella tularensis subspecies tularensis. Scand. J. Infect. Dis. 34, 327-330. doi: 10.1080/00365540110080773

Jones, C. L., Napier, B. A., Sampson, T. R., Llewellyn, A. C., Schroeder, M. R., and Weiss, D. S. (2012). Subversion of host recognition and defense systems by Francisella spp. Microbiol. Mol. Biol. Rev. 76, 383-404. doi: 10.1128/MMBR.05027-11

Katz, J., Zhang, P., Martin, M., Vogel, S. N., and Michalek, S. M. (2006). Toll-like receptor 2 is required for inflammatory responses to Francisella tularensis LVS. Infect. Immun. 74, 2809-2816. doi: 10.1128/IAI.74.5.2809-2816.2006

Kaya, A., Uysal, I. O., Guven, A. S., Engin, A., Gulturk, A., Icagasioglu, F. D., et al. (2011). Treatment failure of gentamicin in pediatric patients with oropharyngeal tularemia. Med. Sci. Monit. 17, CR376-CR380. doi: 10.12659/MSM.881848

KEGG. (2014). Kyoto Encyclopedia of Genes and Genomes [Online]. (Accessed January 15, 2014). Available online at: http://www.genome.jp/kegg/kegg2.html

Kieffer, T. L., Cowley, S., Nano, F. E., and Elkins, K. L. (2003). Francisella novicida LPS has greater immunobiological activity in mice than F. tularensis LPS, and contributes to F. novicida murine pathogenesis. Microbes Infect. 5, 397-403. doi: 10.1016/S1286-4579(03)00052-2

Kim, H. S., Schell, M. A., Yu, Y., Ulrich, R. L., Sarria, S. H., Nierman, W. C., et al. (2005). Bacterial genome adaptation to niches: divergence of the potential virulence genes in three Burkholderia species of different survival strategies. BMC Genomics 6:174. doi: 10.1186/1471-2164-6-174

Kim, T. H., Sebastian, S., Pinkham, J. T., Ross, R. A., Blalock, L. T., and Kasper, D. L. (2010). Characterization of the O-antigen polymerase (Wzy) of Francisella tularensis. J. Biol. Chem. 285, 27839-27849. doi: 10.1074/jbc.M110. 143859

Klimpel, G. R., Eaves-Pyles, T., Moen, S. T., Taormina, J., Peterson, J. W., Chopra, A. K., et al. (2008). Levofloxacin rescues mice from lethal intra-nasal infections with virulent Francisella tularensis and induces immunity and production of protective antibody. Vaccine 26, 6874-6882. doi: 10.1016/j.vaccine.2008. 09.077

Kreizinger, Z., Hornok, S., Dan, A., Hresko, S., Makrai, L., Magyar, T., et al. (2013). Prevalence of Francisella tularensis and Francisella-like endosymbionts in the tick population of Hungary and the genetic variability of Francisella-like agents. Vector Borne Zoonotic Dis. 13, 160-163. doi: 10.1089/vbz.2012.1065

Kugeler, K. J., Gurfield, N., Creek, J. G., Mahoney, K. S., Versage, J. L., and Petersen, J. M. (2005). Discrimination between Francisella tularensis and Francisella-like endosymbionts when screening ticks by PCR. Appl. Environ. Microbiol. 71, 7594-7597. doi: 10.1128/AEM.71.11.7594-7597.2005

Kugeler, K. J., Mead, P. S., Janusz, A. M., Staples, J. E., Kubota, K. A., Chalcraft, L. G., et al. (2009). Molecular epidemiology of Francisella tularensis in the United States. Clin. Infect. Dis. 48, 863-870. doi: 10.1086/597261

Kuske, C. R., Barns, S. M., Grow, C. C., Merrill, L., and Dunbar, J. (2006). Environmental survey for four pathogenic bacteria and closely related species using phylogenetic and functional genes. J. Forensic Sci. 51, 548-558. doi: 10.1111/j.1556-4029.2006.00131.x

Lapage, S. P. (1992). International Code of Nomenclature of Bacteria. Washington, DC: ASM Press. 
Larson, C. L., Wicht, W., and Jellison, W. L. (1955). A new organism resembling $P$. tularensis isolated from water. Public Health Rep. 70, 253-258.

Larsson, P., Elfsmark, D., Svensson, K., Wikström, P., Forsman, M., Brettin, T., et al. (2009). Molecular evolutionary consequences of niche restriction in Francisella tularensis, a facultative intracellular pathogen. PLoS Pathog. 5:e1000472. doi: 10.1371/journal.ppat.1000472

Larsson, P., Oyston, P. C., Chain, P., Chu, M. C., Duffield, M., Fuxelius, H. H., et al. (2005). The complete genome sequence of Francisella tularensis, the causative agent of tularemia. Nat. Genet. 37, 153-159. doi: 10.1038/ng1499

Lauriano, C. M., Barker, J. R., Yoon, S. S., Nano, F. E., Arulanandam, B. P., Hassett, D. J., et al. (2004). MglA regulates transcription of virulence factors necessary for Francisella tularensis intraamoebae and intramacrophage survival. Proc. Natl. Acad. Sci. U.S.A. 101, 4246-4249. doi: 10.1073/pnas.0307690101

Leelaporn, A., Yongyod, S., Limsrivanichakorn, S., Yungyuen, T., and Kiratisin, P. (2008). Francisella novicida bacteremia, Thailand. Emerging Infect. Dis. 14, 1935-1937. doi: 10.3201/eid1412.080435

Lim, K. H., and Staudt, L. M. (2013). Toll-like receptor signaling. Cold Spring Harb. Perspect. Biol. 5:a011247. doi: 10.1101/cshperspect.a011247

Machado-Ferreira, E., Piesman, J., Zeidner, N. S., and Soares, C. A. (2009). Francisella-like endosymbiont DNA and Francisella tularensis virulence-related genes in Brazilian ticks (Acari: Ixodidae). J. Med. Entomol. 46, 369-374. doi: 10.1603/033.046.0224

Maier, T. M., Casey, M. S., Becker, R. H., Dorsey, C. W., Glass, E. M., Maltsev, N., et al. (2007). Identification of Francisella tularensis Himar1-based transposon mutants defective for replication in macrophages. Infect. Immun. 75, 5376-5389. doi: 10.1128/IAI.00238-07

Maier, T. M., Havig, A., Casey, M., Nano, F. E., Frank, D. W., and Zahrt, T. C. (2004), Construction and characterization of a highly efficient Francisella shuttle plasmid. Appl. Environ. Microbiol. 70, 7511-7519. doi: 10.1128/AEM.70.12.75117519.2004

Malik, M., Bakshi, C. S., Sahay, B., Shah, A., Lotz, S. A., and Sellati, T. J. (2006). Tolllike receptor 2 is required for control of pulmonary infection with Francisella tularensis. Infect. Immun. 74, 3657-3662. doi: 10.1128/IAI.02030-05

Mares, C. A., Ojeda, S. S., Morris, E. G., Li, Q., and Teale, J. M. (2008). Initial delay in the immune response to Francisella tularensis is followed by hypercytokinemia characteristic of severe sepsis and correlating with upregulation and release of damage-associated molecular patterns. Infect. Immun. 76, 3001-3010. doi: 10.1128/IAI.00215-08

Mariathasan, S., Weiss, D. S., Newton, K., McBride, J., O'rourke, K., Roose-Girma, M., et al. (2006). Cryopyrin activates the inflammasome in response to toxins and ATP. Nature 440, 228-232. doi: 10.1038/nature04515

McCoy, G. W., and Chapin, C. C. (1912). Studies of plague, a plague-like disease and tuberculosis among rodents in California. J. Infect. Dis. VI, 170-180.

McCrumb, F. R. (1961). Aerosol infection of man with Pasteurella tularensis. Bacteriol. Rev. 25, 262-267.

Mdluli, K. E., Anthony, L. S., Baron, G. S., McDonald, M. K., Myltseva, S. V., and Nano, F. E. (1994). Serum-sensitive mutation of Francisella novicida: association with an ABC transporter gene. Microbiology 140(Pt 12), 3309-3318.

Medina, E. A., Morris, I. R., and Berton, M. T. (2010). Phosphatidylinositol 3kinase activation attenuates the TLR2-mediated macrophage proinflammatory cytokine response to Francisella tularensis live vaccine strain. J. Immunol. 185, 7562-7572. doi: 10.4049/jimmunol.0903790

Meibom, K. L., and Charbit, A. (2010). Francisella tularensis metabolism and its relation to virulence. Front. Microbiol. 1:140. doi: 10.3389/fmicb.2010.00140

Meric, M., Willke, A., Finke, E. J., Grunow, R., Sayan, M., Erdogan, S., et al. (2008). Evaluation of clinical, laboratory, and therapeutic features of 145 tularemia cases: the role of quinolones in oropharyngeal tularemia. APMIS 116, 66-73. doi: 10.1111/j.1600-0463.2008.00901.x

Meshcheriakova, I. S., Kormilitsyna, M. I., Rodionova, I. V., and Konstantinova, N. D. (1995). [The characteristics of new species of pathogenic microorganisms in the genus Francisella]. Zh. Mikrobiol. Epidemiol. Immunobiol. 5, 3-8.

Modise, T., Ryder, C., Mane, S. P., Bandara, A. B., Jensen, R. V., and Inzana, T. J. (2012). Genomic comparison between a virulent type Al strain of Francisella tularensis and its attenuated O-antigen mutant. J. Bacteriol. 194, 2775-2776. doi: 10.1128/JB.00152-12

Molins, C. R., Delorey, M. J., Yockey, B. M., Young, J. W., Sheldon, S. W., Reese, S. M., et al. (2010). Virulence differences among Francisella tularensis subsp. tularensis clades in mice. PLOS ONE 5:e10205. doi: 10.1371/journal.pone. 0010205
Moran, N. A. (2002). Microbial minimalism: genome reduction in bacterial pathogens. Cell 108, 583-586. doi: 10.1016/S0092-8674(02)00665-7

Mortensen, B. L., Fuller, J. R., Taft-Benz, S., Kijek, T. M., Miller, C. N., Huang, M. T., et al. (2010). Effects of the putative transcriptional regulator IclR on Francisella tularensis pathogenesis. Infect. Immun. 78, 5022-5032. doi: 10.1128/IAI. 00544-10

Nano, F. E., and Schmerk, C. (2007). The Francisella pathogenicity island. Ann. N.Y. Acad. Sci. 1105, 122-137. doi: 10.1196/annals.1409.000

Nano, F. E., Zhang, N., Cowley, S. C., Klose, K. E., Cheung, K. K., Roberts, M. J., et al. (2004). A Francisella tularensis pathogenicity island required for intramacrophage growth. J. Bacteriol. 186, 6430-6436. doi: 10.1128/JB.186.19.64306436.2004

Nelson, M., Lever, M. S., Dean, R. E., Pearce, P. C., Stevens, D. J., and Simpson, A. J. (2010). Bioavailability and efficacy of levofloxacin against Francisella tularensis in the common marmoset (Callithrix jacchus). Antimicrob. Agents Chemother. 54, 3922-3926. doi: 10.1128/AAC.00390-10

Okan, N. A., Chalabaev, S., Kim, T. H., Fink, A., Ross, R. A., and Kasper, D. L. (2013). Kdo hydrolase is required for Francisella tularensis virulence and evasion of TLR2-mediated innate immunity. MBio 4, e00638-e00612. doi: $10.1128 / \mathrm{mBio} .00638-12$

Okan, N. A., and Kasper, D. L. (2013). The atypical lipopolysaccharide of Francisella. Carbohydr. Res. 378, 79-83. doi: 10.1016/j.carres.2013.06.015

Olsufiev, N. G., Emelyanova, O. S., and Dunayeva, T. N. (1959). Comparative study of strains of B. tularense in the old and new world and their taxonomy. J. Hyg. Epidemiol. Microbiol. Immunol. 3, 138-149.

Ong, C., Ooi, C. H., Wang, D., Chong, H., Ng, K. C., Rodrigues, F., et al. (2004). Patterns of large-scale genomic variation in virulent and avirulent Burkholderia species. Genome Res. 14, 2295-2307. doi: 10.1101/gr.1608904

Owen, C. R., Buker, E. O., Jellison, W. L., Lackman, D. B., and Bell, J. F. (1964). Comparative studies of Francisella tularensis and Francisella novicida. J. Bacteriol. 87, 676-683.

Pammit, M. A., Budhavarapu, V. N., Raulie, E. K., Klose, K. E., Teale, J. M., and Arulanandam, B. P. (2004). Intranasal interleukin-12 treatment promotes antimicrobial clearance and survival in pulmonary Francisella tularensis subsp. novicida infection. Antimicrob. Agents Chemother. 48, 4513-4519. doi: 10.1128/AAC.48.12.4513-4519.2004

Pechous, R. D., McCarthy, T. R., Mohapatra, N. P., Soni, S., Penoske, R. M., Salzman, N. H., et al. (2008). A Francisella tularensis Schu S4 purine auxotroph is highly attenuated in mice but offers limited protection against homologous intranasal challenge. PLOS ONE 3:e2487. doi: 10.1371/journal.pone. 0002487

Petersen, J. M., Carlson, J., Yockey, B., Pillai, S., Kuske, C., Garbalena, G., et al. (2009a). Direct isolation of Francisella spp. from environmental samples. Lett. Appl. Microbiol. 48, 663-667. doi: 10.1111/j.1472-765X.2009.02589.x

Petersen, J. M., Mead, P. S., and Schriefer, M. E. (2009b). Francisella tularensis: an arthropod-borne pathogen. Vet. Res. 40, 7. doi: 10.1051/vetres:2008045

Petersen, J. M., and Molins, C. R. (2010). Subpopulations of Francisella tularensis ssp. tularensis and holarctica: identification and associated epidemiology. Future Microbiol. 5, 649-661. doi: 10.2217/fmb.10.17

Qin, A., Scott, D. W., and Mann, B. J. (2008). Francisella tularensis subsp. tularensis Schu S4 disulfide bond formation protein B, but not an RND-type efflux pump, is required for virulence. Infect. Immun. 76, 3086-3092. doi: 10.1128/IAI. 00363-08

Ray, H. J., Chu, P., Wu, T. H., Lyons, C. R., Murthy, A. K., Guentzel, M. N., et al. (2010). The Fischer 344 rat reflects human susceptibility to francisella pulmonary challenge and provides a new platform for virulence and protection studies. PLoS ONE 5:e9952. doi: 10.1371/journal.pone.0009952

Respicio-Kingry, L. B., Yockey, M., Yendell, B., Ratard, S., Hand, R., Balsamo, J., et al. (2012). "Laboratory analysis of a Francisella novicida outbreak among prisoners at a Louisiana correctional facility, 2011," in 7th International Conference on Tularemia (Breckenridge, $\mathrm{CO}$ ).

Richard, K., Mann, B. J., Stocker, L., Barry, E. M., Qin, A., Cole, L. E., et al. (2014). Novel catanionic surfactant vesicle vaccines protect against Francisella tularensis LVS and confer significant partial protection against $F$. tularensis Schu S4 strain. Clin. Vaccine Immunol. 21, 212-226. doi: 10.1128/CVI.00738-13

Rohmer, L., Fong, C., Abmayr, S., Wasnick, M., Larson Freeman, T. J., Radey, M., et al. (2007). Comparison of Francisella tularensis genomes reveals evolutionary events associated with the emergence of human pathogenic strains. Genome Biol. 8:R102. doi: 10.1186/gb-2007-8-6-r102 
Sampson, T. R., Saroj, S. D., Llewellyn, A. C., Tzeng, Y. L., and Weiss, D. S. (2013). A CRISPR/Cas system mediates bacterial innate immune evasion and virulence. Nature 497, 254-257. doi: 10.1038/nature12048

Sampson, T. R., and Weiss, D. S. (2013a). Alternative roles for CRISPR/Cas systems in bacterial pathogenesis. PLoS Pathog. 9:e1003621. doi: 10.1371/journal.ppat.1003621

Sampson, T. R., and Weiss, D. S. (2013b). Degeneration of a CRISPR/Cas system and its regulatory target during the evolution of a pathogen. RNA Biol. 10, 1618-1622. doi: 10.4161/rna.26423

Schmerk, C. L., Duplantis, B. N., Howard, P. L., and Nano, F. E. (2009). A Francisella novicida pdpA mutant exhibits limited intracellular replication and remains associated with the lysosomal marker LAMP-1. Microbiology 155, 1498-1504. doi: 10.1099/mic.0.025445-0

Schunder, E., Rydzewski, K., Grunow, R., and Heuner, K. (2013). First indication for a functional CRISPR/Cas system in Francisella tularensis. Int. J. Med. Microbiol. 303, 51-60. doi: 10.1016/j.ijmm.2012.11.004

Scoles, G. A. (2004). Phylogenetic analysis of the Francisella-like endosymbionts of Dermacentor ticks. J. Med. Entomol. 41, 277-286. doi: 10.1603/0022-258541.3.277

Sharma, J., Li, Q., Mishra, B. B., Pena, C., and Teale, J. M. (2009). Lethal pulmonary infection with Francisella novicida is associated with severe sepsis. J. Leukoc. Biol. 86, 491-504. doi: 10.1189/jlb.1208728

Sjödin, A., Svensson, K., Ohrman, C., Ahlinder, J., Lindgren, P., Duodu, S., et al. (2012). Genome characterisation of the genus Francisella reveals insight into similar evolutionary paths in pathogens of mammals and fish. BMC Genomics 13:268. doi: 10.1186/1471-2164-13-268

Skerman, V. B. D., McGowan, V., and Sneath, P. H. A., (eds.). (1980). Approved lists of bacterial names. Int. J. Syst. Bacteriol. 30, 225-420.

Stackebrandt, E., Frederiksen, W., Garrity, G. M., Grimont, P. A., Kampfer, P., Maiden, M. C., et al. (2002). Report of the ad hoc committee for the reevaluation of the species definition in bacteriology. Int. J. Syst. Evol. Microbiol. 52, 1043-1047. doi: 10.1099/ijs.0.02360-0

Steward, J., Piercy, T., Lever, M. S., Simpson, A. J., and Brooks, T. J. (2006). Treatment of murine pneumonic Francisella tularensis infection with gatifloxacin, moxifloxacin or ciprofloxacin. Int. J. Antimicrob. Agents 27, 439-443. doi: 10.1016/j.ijantimicag.2006.02.006

Sutera, V., Levert, M., Burmeister, W. P., Schneider, D., and Maurin, M. (2014). Evolution toward high-level fluoroquinolone resistance in Francisella species. J. Antimicrob. Chemother. 69, 101-110. doi: 10.1093/jac/dkt321

Svensson, K., Sjödin, A., Bystrom, M., Granberg, M., Brittnacher, M. J., Rohmer, L., et al. (2012). Genome sequence of Francisella tularensis subspecies holarctica strain FSC200, isolated from a child with tularemia. J. Bacteriol. 194, 6965-6966. doi: 10.1128/JB.01040-12

Tärnvik, A., and Berglund, L. (2003). Tularaemia. Eur. Respir. J. 21, 361-373. doi: 10.1183/09031936.03.00088903

Telepnev, M., Golovliov, I., Grundström, T., Tärnvik, A., and Sjöstedt, A. (2003). Francisella tularensis inhibits Toll-like receptor-mediated activation of intracellular signalling and secretion of TNF-alpha and IL-1 from murine macrophages. Cell. Microbiol. 5, 41-51. doi: 10.1046/j.1462-5822.2003. 00251.x

Tempel, R., Lai, X. H., Crosa, L., Kozlowicz, B., and Heffron, F. (2006). Attenuated Francisella novicida transposon mutants protect mice against wild-type challenge. Infect. Immun. 74, 5095-5105. doi: 10.1128/IAI.00598-06

Thomas, R. M., Titball, R. W., Oyston, P. C., Griffin, K., Waters, E., Hitchen, P. G., et al. (2007). The immunologically distinct O antigens from Francisella tularensis subspecies tularensis and Francisella novicida are both virulence determinants and protective antigens. Infect. Immun. 75, 371-378. doi: 10.1128/IAI. 01241-06

Thomas, R. M., Twine, S. M., Fulton, K. M., Tessier, L., Kilmury, S. L., Ding, W., et al. (2011). Glycosylation of DsbA in Francisella tularensis subsp. tularensis.J. Bacteriol. 193, 5498-5509. doi: 10.1128/JB.00438-11

Tindall, B. J., Kampfer, P., Euzeby, J. P., and Oren, A. (2006). Valid publication of names of prokaryotes according to the rules of nomenclature: past history and current practice. Int. J. Syst. Evol. Microbiol. 56, 2715-2720. doi: 10.1099/ijs.0.64780-0

Tomaso, H., Al Dahouk, S., Hofer, E., Splettstoesser, W. D., Treu, T. M., Dierich, M. P., et al. (2005). Antimicrobial susceptibilities of Austrian Francisella tularensis holarctica biovar II strains. Int. J. Antimicrob. Agents 26, 279-284. doi: 10.1016/j.ijantimicag.2005.07.003

Urich, S. K., and Petersen, J. M. (2008). In vitro susceptibility of isolates of Francisella tularensis types A and B from North America. Antimicrob. Agents Chemother. 52, 2276-2278. doi: 10.1128/AAC.01584-07

Valade, E., Vaissaire, J., Merens, A., Hernandez, E., Gros, C., Le Doujet, C., et al. (2008). Susceptibility of 71 French isolates of Francisella tularensis subsp. holarctica to eight antibiotics and accuracy of the Etest method. J. Antimicrob. Chemother. 62, 208-210. doi: 10.1093/jac/dkn146

Vinogradov, E., Conlan, W. J., Gunn, J. S., and Perry, M. B. (2004). Characterization of the lipopolysaccharide O-antigen of Francisella novicida (U112). Carbohydr. Res. 339, 649-654. doi: 10.1016/j.carres.2003.12.013

Vinogradov, E., and Perry, M. B. (2004). Characterisation of the core part of the lipopolysaccharide O-antigen of Francisella novicida (U112). Carbohydr. Res. 339, 1643-1648. doi: 10.1016/j.carres.2004.04.013

Vinogradov, E., Perry, M. B., and Conlan, J. W. (2002). Structural analysis of Francisella tularensis lipopolysaccharide. Eur. J. Biochem. 269, 6112-6118. doi: 10.1046/j.1432-1033.2002.03321.x

Weber, I. B., Turabelidze, G., Patrick, S., Griffith, K. S., Kugeler, K. J., and Mead, P. S. (2012). Clinical recognition and management of tularemia in Missouri: a retrospective records review of 121 cases. Clin. Infect. Dis. 55, 1283-1290. doi: $10.1093 / \mathrm{cid} / \mathrm{cis} 706$

Weiss, D. S., Brotcke, A., Henry, T., Margolis, J. J., Chan, K., and Monack, D. M. (2007a). In vivo negative selection screen identifies genes required for Francisella virulence. Proc. Natl. Acad. Sci. U.S.A. 104, 6037-6042. doi: 10.1073/pnas.0609675104

Weiss, D. S., Henry, T., and Monack, D. M. (2007b). Francisella tularensis: activation of the inflammasome. Ann. N.Y. Acad. Sci. 1105, 219-237. doi: 10.1196/annals.1409.005

Whipp, M. J., Davis, J. M., Lum, G., De Boer, J., Zhou, Y., Bearden, S. W., et al. (2003). Characterization of a novicida-like subspecies of Francisella tularensis isolated in Australia. J. Med. Microbiol. 52, 839-842. doi: 10.1099/jmm.0. 05245-0

Whitehouse, C. A., Kesterson, K. E., Duncan, D. D., Eshoo, M. W., and Wolcott, M. (2012). Identification and characterization of Francisella species from natural warm springs in Utah, USA. Lett. Appl. Microbiol. 54, 313-324. doi: 10.1111/j.1472-765X.2012.03214.x

WHO. (2007). WHO Guidelines on Tularaemia. Geneva: World Health Organization.

Zarrella, T. M., Singh, A., Bitsaktsis, C., Rahman, T., Sahay, B., Feustel, P. J., et al. (2011). Host-adaptation of Francisella tularensis alters the bacterium's surfacecarbohydrates to hinder effectors of innate and adaptive immunity. PLoS ONE 6:e22335. doi: 10.1371/journal.pone.0022335

Zimmer, A. L., Thoden, J. B., and Holden, H. M. (2013). Three-dimensional structure of a sugar N-formyltransferase from Francisella tularensis. Protein Sci. doi: 10.1002/pro.2409. [Epub ahead of print].

Zogaj, X., Wyatt, G. C., and Klose, K. E. (2012). Cyclic di-GMP stimulates biofilm formation and inhibits virulence of Francisella novicida. Infect. Immun. 80, 4239-4247. doi: 10.1128/IAI.00702-12

Conflict of Interest Statement: The authors declare that the research was conducted in the absence of any commercial or financial relationships that could be construed as a potential conflict of interest.

Received: 12 December 2013; accepted: 22 February 2014; published online: 13 March 2014.

Citation: Kingry LC and Petersen JM (2014) Comparative review of Francisella tularensis and Francisella novicida. Front. Cell. Infect. Microbiol. 4:35. doi: 10.3389/ fcimb.2014.00035

This article was submitted to the journal Frontiers in Cellular and Infection Microbiology.

Copyright (C) 2014 Kingry and Petersen. This is an open-access article distributed under the terms of the Creative Commons Attribution License (CC BY). The use, distribution or reproduction in other forums is permitted, provided the original author(s) or licensor are credited and that the original publication in this journal is cited, in accordance with accepted academic practice. No use, distribution or reproduction is permitted which does not comply with these terms. 